DOI 10.37882/2223-2982.2020.10.14

\title{
НАЦИОНАЛЬНО-КУЛЬТУРНЫЙ СМЫСЛ АНГЛИЙСКОЙ ПОСЛОВИЦЫ
}

\section{NATIONAL AND CULTURAL MEANING OF ENGLISH PROVERBS}

\section{T. Golikova}

Summary: The article considers valuable features of the English character and rules of behavior in society in the mirror of the English proverb. The conclusions are based on the analysis of a large body of examples from the online dictionary of English Proverbs. The main valuable traits of the English character are patience, endurance, decency, responsibility for their actions, hard work. The basic rules of behavior in English society - caution, distance in relations with people, secrecy. Don't judge people superficially or based on first impressions. In addition, the article discusses the specifics of English, Irish, Scottish, and Welsh Proverbs.

Keywords: picture of the world, folk wisdom, local colour.
Голикова Татьяна Олеговна

К.филол.н., дочент, Российская Академия Народного Хозяйства и Государственной Службы при Президенте Российской Федерации, г. Москва tatianagolikova73@yandex.ru

Аннотация: В статье рассматриваются ценные черты английского характера и правила поведения в обществе в зеркале английской пословицы. Выводы сделаны на основе анализа большого корпуса примеров из онлайн словаря английских пословиц. Основными ценными чертами английского характера являются терпение, выдержка, порядочность, ответственность за свои поступки, трудолюбие. Основные правила поведения в английском обществе - осторожность, дистанция в отношениях с людьми, скрытность. Не надо судить о людях поверхностно или по первому впечатлению. Помимо этого, в статье рассматривается специфика английских, ирландских, шотландских, валлийских пословиц.

Ключевые слова: картина мира, народная мудрость, местный колорит.

Правильным отношением к жизни считается осторожность, дистанция в отношениях с людьми, даже скрытность [1]:

\section{All truths are not to be told;}

Ask no questions, and you will be told no lies; Discretion is the better part of valour. кое изречение становилось пословицей, а только такое, которое согласовывалось с образом жизни и мыслями множества людей, - такое изречение могло существовать тысячелетия, переходя из века в век» [2.с.94].

Что же мы должны знать о пословицах, и, в частности, об английских пословицах? Как они отражают картину мира англичан? Каким должен быть человек, исходя из английской народной мудрости? Какие человеческие качества ценятся и какие советы даются? Как нужно себя вести человеку в обществе? Поиск ответа на эти вопросы и является целью данной статьи.

Автором проведен анализ словаря английских пословиц [1]. Методом сплошной выборки выделялись, а затем группировались по смыслу изречения, дающие ответы на эти вопросы. Поскольку анализ проводился на глазок, без помощи точных методов подсчета и без помощи компьютерных программ, он ни в коей мере не претендует на полноту и дает возможность сделать лишь предварительные выводы.

1. Наибольшее число английских пословиц называют ценными терпение и выдержку [1]:

Patience is a plaster for all sores;

Anger and haste hinder good counsel;

First think, then speak;

Think before you speak.

Не надо слишком открыто демонстрировать свое рвение к работе, старательность. Пословицы предупреждают о том, что на слишком старательного человека могут возложить слишком много дел [1]:

All lay loads on a willing horse.

2. В английских пословицах в человеке прежде всего ценятся порядочность и ответственность за свои поступки:

Actions speak louder than words;

Promise is debt;

Promise little, but do much.

Каждый должен нести ответственность за последствия своих действий [1]:

As you brew, so you must drink;

As you make your bed, so you must lie on it;

As you sow, so you reap (You reap what you sow).

3. На втором месте в английских пословицах стоит трудолюбие [1]:

Never put off till tomorrow what you can do today;

By doing nothing we learn to do ill.

Не надо искать себе оправданий, если делаешь чтото плохо [1]: 


\section{A bad workman always blames his tools.}

4. Третье место занимает вежливость [1]:

All doors open to courtesy;

Politeness costs little, but yields much.

5. Главный совет английских пословиц - не судить о людях поверхностно или по первому впечатлению [1]:

All are not thieves that dogs bark at.

All are not friends that speak us fair;

All are not saints that go to church;

All that glitters is not gold;

Appearances are deceitful;

Beauty is only skin deep;

The bait hides the hook;

False friends are worse than open enemies.

6. Кроме того, пословицы говорят: надо ценить дружбу, друзей, помогать друзьям [1]:

Among friends all things are common;

A friend in need is a friend indeed.

Но не нужно забывать и о себе [1]:

Friendship cannot stand always on one side.

По английской народной мудрости человеку не надо быть нетерпеливым [1]:

All in good time.

В жизни надо использовать все шансы, все возможности [1]:

All is fish that comes to the net.

7. Дается еще один совет, совсем из другой области. Человек должен вести активный образ жизни, быть здоровым [1]:

Early to bed and early to rise makes a man healthy, wealthy and wise;

After dinner sit a while, after supper walk a mile.

На таком очень неполном материале позволим себе наметить некоторые штрихи к психологическому портрету англичан. Они считают, что человек должен быть выдержанным, должен отвечать за свои слова и поступки. Человек должен быть трудолюбивым и активным. Он должен быть вежливым. При этом подчеркивается, что не всегда в жизни нужно быть открытым, и часто приходится вести себя скрытно, оберегая свой мир от посторонних.

Сравним эти черты с полными и обоснованными выводами, которые делает антрополог Кейт Фокс в книге «Наблюдая за англичанами». На основе многих психологических экспериментов, К. Фокс выделяет черты английского характера. Это сдержанность, а также скрытность и осторожность (English reserve): боязнь близких дружеских отношений с людьми и прямого открытого общения. Это консерватизм. Это знаменитое английское лицемерие, которое пронизывает все сферы жизни и поведения, и даже объясняет идеалы англичан, в частности скромность и вежливость. В поведении важнейшей нормой является вежливость, имеющая глубокие корни, часто безотчетная, но во многих случаях требующая сознательных усилий [4. с.401-408].

Таким образом, наши наблюдения подтверждают знаменитые черты английского характера и правила поведения в обществе. В перспективе для дальнейшего исследования остается вопрос: «Почему именно такие черты и правила присущи англичанам?». Также в перспективе для исследования остается сравнение английской и русской народной мудрости.

Здесь можно было бы поставить точку, если бы не еще один, очень важный аспект английских пословиц. Великобритания многонациональна и многокультурна. Помимо Англии (в узком смысле слова), она включает Северную Ирландию, Шотландию, Уэльс. Существуют не только английские, но и ирландские, шотландские, валлийские пословицы. Можно предположить, что у всех этих пословиц есть что-то общее. Однако, пословицы каждого народа (ирландцев, шотландцев, валлийцев) не могут не иметь неповторимый колорит.

При сравнении английских, ирландских, шотландских, валлийских пословиц нельзя не отметить, что наиболее ценным качеством человека все они называют трудолюбие, а отрицательными качествами - леность и праздность.

В Англии говорят:

Never put off till tomorrow what you can do today;

By doing nothing we learn to do ill [1].

В Ирландии говорят:

Keep your shop and your shop will keep you;

Laziness is a heavy burden;

Poverty waits at the gates of idleness [5].

В Шотландии скажут:

Nae gains without pains;

Nae sweat, nae sweet;

Naething is got without pains but an ill fame;

Naething is sae difficult but may be overcome with' perseverance;

Perseverance performs greater works than strength; Frugality is a fair fortune, and industry a good estate; Plough deep while sluggards sleep. [7].

Валлийцы скажут:

Your hand is never the worse for doing its own work; The seed of evil is laziness;

No good will come of oversleeping;

Work ill done must be twice done; 
Without perseverance talent is a barren bed. [8].

Помимо этой общей черты, при сравнении пословии нельзя не отметить и специфические черты ирландских, шотландских, валлийских послович.

В ирландских пословицах выше всего ценится честь и достоинство [5]:

Better good manners than good looks;

It's more difficult to maintain honour than to become prosperous;

A man may live after losing his life but not after losing his honour;

Better to be a man of character than a man of means;

Better the trouble that follows death than the trouble that follows shame. [7]:

Шотландские пословицы много говорят о храбрости

A courageous foe is better than a cowardly friend;

A faint heart never won a fair lady;

Courage against misfortune, and reason against passion;

Также они высоко ценят благодарность [7]:

Ae good turn deserves another;

Gratitude preserves auld friendships and begets new;

He that gies to a grateful man, puts out at interest.

Шотландские пословицы прославляют честность [7]:

Confessed faults are half mended;

Honesty may be dear bought, but can ne'er be an ill pennyworth;

O'a' crafts to be an honest man is the master-craft.

Они говорят о важности доброты [7]:

A kindly word cools anger;

If I'm no kind, I'm no cumbersome;

Kindness overcomes a dislike.

Шотландские пословицы осуждают жадность, трусость, зависть [7].

О жадности:

Avarice generally miscalculates, and as generally deceives;

Mony ane for land, taks a fool by the hand.

О трусости:

A coward's nae company;

He's mair fleyed than hurt;

His heart's in his hose.

О зависти:

Envy is the rack of the soul, and torture of the body; Envy ne'er does a gude turn, but when it means an ill one.
В валлийских пословицах ценятся совесть, настойчивость, терпение, мудрость [8]:

Conscience is the nest where all good is hatched.

Without perseverance talent is a barren bed;

Tapping persistently breaks the stone;

Patience is the mother of all wisdom;

Reason is the wise man's guide, example the fool's;

The advice of the aged will not mislead you.

Они осуждают поспешность, гнев, лень:

The greater the hurry, the more obstacles there are;

Anger is the mother of treachery;

The seed of evil is laziness.

Валлийские пословицы говорят о важности жизненного опыта [8]:

Adversity and loss make a man wise;

Adversity brings knowledge, and knowledge wisdom.

Они призывают делать добро [8]:

Do good and then do it again;

Repay evil with good and hell will not claim you;

Точно и метко они предостерегают они против лживости [8]:

He who deceives shall be deceived.

Таким образом, в английских, шотландских, ирландских, валлийских пословицах видно своеобразие менталитета и картины мира каждого из народов Великобритании.

Что ещё можно сказать об английских, шотландских, ирландских, валлийских пословицах? В них очень много жизненных и культурных реалий англичан, шотландцев, ирландцев, валлийцев.

Например, английские пословицы содержат много единиц неметрической системы мер, характерной для англоговорящих стран:

1. Don't measure other people's corn by your own bushel (Не меряй на свой аршин).

Bushel (бушель) - традиционная английская мера объема (особенно для зерна, овощей, фруктов), равная 36,369 кубическим дециметрам [6].

2. Mere words will not fill a bushel (Из спасиба шапки не сошьёшь).

Здесь bushel - мерный сосуд вместимостью один бушель [6].

3. You cannot get a quart into a pint pot (Бочку в наперсток не выльешь).

A quart (кварта) и a pint (пинта) - традиционные меры жидкости в англоговорящих странах.

4. Give him an inch and he will take a yard (Дай емy палец, а он всю руку откусит).

An inch (дюйм) и a yard (ярд) - известные меры длины 
в англоговорящих странах.

Ирландские пословицы содержат географические и культурные реалии Ирландии:

1. A Kerry shower is of twenty-four hours.

Kerry - графство на юго-западе Ирландии, популярное у туристов благодаря красивым горам и сельским пейзажам [6].

2. Never call a Kerry man a fool until you're sure he's not a rogue.

Здесь делается намек на какую-то черту характера людей из графства Керри, возможно лицемерие или двуличность.

3.Limerick was, Dublin is and Cork shall be the finest city of the three.

Limerick (Лимерик) - главный город графства на югозападе Республики Ирландия [6].

Dublin - столица Республики Ирландия. Это центр культуры. В Дублине жили писатели Джонотан Свифт, Джордж Бернард Шоу, Оскар Уайльд, Джеймс Джойс. О Дублине сложено много известных песен [6].

Cork - второй по величине город Республики Ирландия, столица самого большого графства.

\section{You couldn't make half a football team out of all} the Leinster men in heaven.

Leinster (Ленстер) - провинция Республики Ирландия, которая включает 12 графств и город Дублин [6]. Жителей этой провинции пословица показывает людьми грешными со множеством пороков: очень мало жителей Ленстера можно найти в Раю (не наберется и половины футбольной команды).

\section{You kissed the blarney stone.}

Так говорят о человеке, который имеет дар убеждать других и добиваться своей цели. The Blarney stone (камень Бларни) - камень в стене замка Бларни в Ирландии. Существует поверье, что, если его поцеловать, это при- несет удачу и способность убедить людей сделать так, как вам хочется [6].

В шотландских пословицах находят отражение особенности произношения шотландского диалекта английского языка:

1. A bird in the hand is worth ten fleein';

2. Beggars cannae be choosers;

3. It's an ill wind that blaws naebody any gude;

4. Time and tide tarry on nae man;

5. The fit (foot) on the cradle,

The hand on the reel,

Is the sign o'a woman that means to do weel;

6. Naething is sae difficult but may be overcome wi' perseverance.

Что касается валлийских пословиц, то они самые самобытные, оригинальные. В них меньше всего английских заимствований. Валлийские пословицы очень красивые и краткие. Они подчеркивают важную роль языка в жизни народа [8]:

A nation without a language is a nation without a heart.

В целом, английские, шотландские, ирландские, валлийские пословицы - ключ к пониманию культурного многообразия Великобритании.

Пословицы представляют исключительно интересный материал для изучения и обсуждения на занятиях английского языка. Они являются бесценным источником информации о реалиях и культуре Великобритании: Англии, Шотландии, Ирландии, Уэльса. Также они предлагают прекрасные темы для дискуссии, на основе которых можно и нужно формировать речевые навыки.

\section{ЛИТЕРАТУРА}

1. Английские пословицы (словарь английских пословиц). - Режим доступа: English-4life.com.ua/poslovit/poslovit.html (дата 0бращения: 18.01.2018).

2. Верещагин Е.М., Костомаров В.Г. Язык и культура (лингвострановедение в преподавании русского языка как иностранного). - М: Русский язык, 1983. - 269 с.

3. Карасик В.И. Языковой круг: личность, концепты, дискурс. - Волгоград: Перемена, 2002. - 331 с.

4. Fox K. Watching the English (the hidden rules of English behavior). - London, Hodder and Stoughton Ltd, 2004. - $424 \mathrm{p}$.

5. Irish proverbs. - Режим доступа: islandireland.com/Pages/folk/sets/proverb.html (дата обращения: 21.09.2020).

6. Longman Dictionary of English Language and Culture. - Harlow: Longman, 2000. - 1566 c.

7. Scottish proverbs. - Режим доступа: electricscotland.com/humour/scottish-proverbs.pdf (дата обращения: 31.01.2018).

8. Welsh proverbs. - Режим доступа: proverbicals.com/welsh-proverbs (дата обращения: 21.09.2020). 